\title{
СТАН АНТИОКСИДАНТНОЇ ГЛУТАТІОНОВОЇ СИСТЕМИ ТА ПРОЦЕСІВ ПЕРЕКИСНОГО ОКИСНЕННЯ ЛІПІДІВ У ЛЕГЕНЯХ МОРСЬКИХ СВИНОК 3 ЕКСПЕРИМЕНТАЛЬНИМ АЛЕРГІЧНИМ АЛЬВЕОЛІТОМ У РІЗНІ ПЕРІОДИ ФОРМУВАННЯ
}

Львівський національний медичний університет ім. Данила Галицького

\begin{abstract}
Резюме. У даній роботі встановлено, що за умов розвитку експериментального алергічного альвеоліту на 34-ту та 44-ту доби зростає концентрація малонового альдегіду за рахунок посилення процесів перекисного окиснення ліпідів. До того ж на 44-ту добу спостерігається зниження активності глутатіонпероксидази та глутатіонредуктази, а також концентрації відновленого глутатіону. Дані зміни вказують, що в патогенезі розвитку експериментального алергічного альвеоліту в мор-
\end{abstract}

Вступ. За останні десять років значно зросла кількість досліджень, результати яких вказують на важливу роль у патогенезі розвитку екзогенного алергічного альвеоліту порушення балансу між прооксидантами та антиоксидантною системою. Активовані клітини запалення акумулюються в нижніх відділах дихальної системи та продукують прозапальні метаболіти, до яких відносяться і вільні радикали. Дані сполуки зумовлюють ураження клітин паренхіми легень, зміну іï структури, шляхом індукції процесів фіброзу. Основна роль у регуляції даних процесів належить антиоксидантній системі $[1,2,9]$.

Відомо, що антиоксидантна система (АОС) складається 3 ферментативної та неферментативної ланок. До неферментативної належать: гідрофільні метаболіти (відновлений глутатіон, аскорбінова кислота) та ліпофільні метаболіти (каротиноїди, токоферол). До ферментативної ланки належать: каталаза, супероксиддисмутаза та глутатіонпероксидаза. 3 джерел літератури відомо, що концентрація відновленого глутатіону в легеневій тканині в 140 разів вища за концентрацію даного метаболіту в крові, що вказує на важливість глутатіонової системи в антиоксидантному захисті у легеневій тканині $[2,7,10,12]$.

Дана система складається з відновленої форми глутатіону (ВГ), глутатіонпероксидази (ГПО), глутатіонредуктази (ГР) та глутатіонтрансферази (ГТ). ВГ за участю NADPH під впливом ГПО взаємодіє 3 вільними радикалами та інактивує токсичну дію їх внаслідок окиснення глутатіону. Відновлюється окиснений глутатіон під впливом ГР, яка індукується за умов оксидативного стресу $[11,5,8]$.

Також відомо, що ВГ бере активну участь у процесах мукоцеліарного транспорту. Враховуючи хімічну будову ВГ, яка $є$ подібною до будови молекули $\mathrm{N}$-ацетилцистеїну, даний метаболіт здатний розщеплювати дисульфідні зв'язки, тим самим зменшує в'язкість слизу. Крім того, ВГ відіграє важливу роль у процесах гідрації слизу (С) Б.Я. Мелех, 2016 ських свинках важливу роль відіграють процеси перекисного окиснення ліпідів та ферментативної і неферментативної ланки антиоксидантної системи, а також значне виснаження ферментативної ланки антиоксидантної глутатіонової системи на 44-ту добу.

Ключові слова: глутатіон, глутатіонпероксидаза, глутатіонредуктаза, глутатіонтрансфераза, експериментальний алерігчний альвеоліт.

через його непрямий зв'язок із натрієвими каналами епітеліальних клітин.

У доступній нам літературі відсутні дослідження, які стосуються вивченню стану глутатіонової системи за умов розвитку екзогенного алергічного альвеоліту.

Мета дослідження. Оцінити стан глутатіонової антиоксидантної системи та процесів перекисного окиснення ліпідів (ПОЛ) у легенях морських свинок 3 експериментальним алергічним альвеолітом у різні періоди його формування.

Матеріал і методи. Експериментальні дослідження проведені на 31 морській свинці самцях середньою масою тіла 280-320 г. Контрольна група складалася з 15 інтактних самців. Першу дослідну групу становили вісім тварин з експериментальним алергічним альвеолітом (ЕАА), які були виведені з експерименту на 34-ту добу від початку дослідження. Друга дослідна група містила вісім тварин з ЕАА, які були виведені з експерименту на 44-ту добу від початку дослідження. Усіх експериментальних тварин утримували в стандартних умовах віварію Львівського національного медичного університету імені Данила Галицького.

Експериментальний ЕАА відтворюється за методом О.О. Орехова, Ю.А. Кириллова [2]. Попередньо тварин імунізували повним ад'ювантом Фрейнда (0,2 мл у задню лапку внутрішньом'язово). Через два тижні після імунізації тваринам кожні 10 днів уводили внутрішньовенно по 0,2 мл $1 \%$ розчину бацили Кальмета-Жерена (БЦЖ). Експериментальних тварин виводили з експерименту шляхом декапітації та визначали біохімічні показники відносно встановлених методик у гомогенаті легень. Інтенсивність оксидативного стресу оцінювали за активністю утворення основного продукту перекисного окиснення ліпідів малонового альдегіду (МА), який визначали в сироватці крові методом Тімірбулатова Р.А. та Селезньова Є.I. [6]. Вміст ВГ визначали на основі реакції з реактивом Елмана [4]. Активність ГПО, 
Таблиця

Зміни показників антиоксидантної системи за умов розвитку алергічного альвеоліту

\begin{tabular}{|c|c|c|c|c|c|}
\hline $\begin{array}{l}\text { Показник } \\
\text { Група }\end{array}$ & $\begin{array}{c}\text { МА } \\
\text { Нмоль/мл }\end{array}$ & $\begin{array}{c}\text { ВГ } \\
\text { Ммоль/л }\end{array}$ & $\begin{array}{c}\text { ГПО } \\
\text { Ммоль/хв*г } \\
\mathrm{Hb}\end{array}$ & $\begin{array}{c}\text { ГР } \\
\text { Мкмоль } \\
\text { НАДФН }{ }_{2} / \text { хв }^{*} \text { г } \mathrm{Hb}\end{array}$ & $\begin{array}{c}\text { ГТ } \\
\text { Мкмоль } \\
\text { GSSG/хв*г } \\
\mathrm{Hb}\end{array}$ \\
\hline $\begin{array}{c}\text { Контрольна група } \\
\text { (інтактна група тварин), } \\
(\mathrm{n}=15)\end{array}$ & $29,51 \pm 3,46$ & $6,15 \pm 1,12$ & $9,51 \pm 1,12$ & $4,55 \pm 0,35$ & $3,49 \pm 0,28$ \\
\hline $\begin{array}{c}\text { Перша дослідна група, } \\
\text { 34-та доба }(\mathrm{n}=8)\end{array}$ & $48,23 \pm 4,52 *$ & $3,22 \pm 1,04 *$ & $8,48 \pm 1,76$ & $3,93 \pm 0,48$ & $3,22 \pm 0,39$ \\
\hline $\begin{array}{c}\text { Друга дослідна група, } \\
44-\text { та доба (n=8) }\end{array}$ & $43,79 \pm 4,05 *$ & $3,07 \pm 1,47 *$ & $6,01 \pm 1,44 *$ & $2,74 \pm 0,46^{*}$ & $3,25 \pm 0,25$ \\
\hline
\end{tabular}

Примітка. ${ }^{*}$ - достовірність $(\mathrm{p}<0,05)$ порівняно $з$ контрольною групою тварин

ГТ та ГР визначали за методом Переслегіної І.А. $[3]$.

Статистичну обробку даних проводили 3 використанням програми Statistica 6.0.

Результати дослідження та їх обговорення. Результати даного дослідження показали, що глутатіонова антиоксидантна система істотно реагує на зміну активності прооксидантів за умов EAA.

Результати даного дослідження показали достовірне зростання концентрації МА на $63,44 \%(p<0,05)$ у першій дослідній групі та на $48,39 \%(p<0,05)$ у другій дослідній групі при порівнянні з контролем. Істотне зростання концентрації МА, як кінцевого продукту ПОЛ, вказує на посилення процесів перекисного окиснення ліпідів на 34-ту та 44-ту доби у крові морських свинок за умов розвитку ЕАА. Водночас спостерігається достовірне зниження концентрації ВГ на 47,64 \% (p<0,05) у першій дослідній групі та на $50,10 \%(\mathrm{p}<0,05)$ у другій дослідній групі при порівнянні 3 інтактними тваринами. Зокрема, встановлене зниження концентрації ВГ у дослідних групах вказує на депресію потенціалу неферментативної ланки антиоксидантного захисту на 34-ту та 44-ту доби, також на погіршення мукоцеліарного транспорту та процесів гідрації слизу, що призводить до посилення запальних процесів у термінальних відділах дихальної системи. Дискогерентні зміни з боку концентрації МА та ВГ дають підставу стверджувати, що на 34-ту на 44ту доби в патогенезі ЕАА важливу роль відіграє наявність оксидативного стресу. 3 боку ферментативної ланки глутатіонової антиоксидантної системи зазнають достовірних змін лише активності ГПО та ГР: на 44-ту добу знижується активність ГПО на 36,80\% $(\mathrm{p}<0,05)$ та активність ГР на $39,78 \%(\mathrm{p}<0,05)$ порівняно 3 інтактними тваринами. Дані зміни вказують на виснаження ферментативної ланки глутатіонової антиоксидантної системи на 44-ту добу за умов розвитку ЕАА. Це зумовлено як зниженням концентрації основного метаболіту даної системи, так і альтерацією ГПО та ГР вільними радикалами за умов розвитку оксидативного стресу.
У ході експерименту достовірної різниці в активностях ГТ дослідних груп проти інтактних тварин не виявлено, відповідно детоксикаційна функція антиоксидантної глутатіонової системи істотних змін не зазнавала.

\section{Висновки}

1. У патогенезі розвитку експериментального алергічного альвеоліту в морських свинках важливу роль відіграють процеси перекисного окиснення ліпідів та ферментативної і неферментативної ланок антиоксидантної системи.

2. Зниження концентрації відновної форми глутатіону на 34-ту та 44-ту доби в морських свинках з експериментальним алергічним альвеолітом вказує на виснаження неферментативної ланки антиоксидантної системи та зумовлює зниження мукоцеліарного транспорту та гідрації слизу, що призводить до розвитку оксидативного стресу і посилення запальних процесів у дистальних відділах дихальної системи. На 44-ту добу в морських свинках з експериментальним алергічним альвеолітом відбувається також виснаження ферментативної ланки антиоксидантної глутатіонової системи.

3. Дані зміни вказують на доцільність використання в терапії експериментального алергічного альвеоліту засобів $з$ антиоксидантними властивостями.

Перспектива подальших досліджень передбачає вивчення впливу засобів з і глутатіонової антиоксидантної системи в легенях та крові морських свинок 3 експериментальним алергічним альвеолітом.

\section{Література}

1. Илькович М.М. Экзогенный аллергический альвеолит / М.М. Илькович, Л.Н. Новикова // Интерстициальные заболевания легких. Под редакцией М.М. Ильковича, А.Н. Кокосова. - СПб., 2005. - С. 183-211.

2. Орехов О.О. Патоморфология легких и микроциркуляторного русла малого круга кровообращения при хроническом экспериментальном аллергическом альвеолите / О.О. Орехов, Ю.А. Кириллов // Арх. патол. 1985. - № 10. - C. 54-61.

3. Переслегина И.А. Активность антиоксидантных ферментов слюны здоровых детей / И.А. Переслегина // Лаб. дело. - 1989. - № 11. - С. 20-23. 
4. Путилина Ф. Определение содержания восстановленного глутатиона в тканях // Кн.: Прохорова М. (ред.). Методы биохимических исследований. - Ленинградский университет, 1982. - С. 183-187.

5. Регеда М.С. Екзогенний алергічний альвеоліт: монографія / М. С. Регеда, Р.Ю. Грицко, І.Г. Гайдучок. 2-ге видання, доповнене і перероблене. - Львів, 2007. $200 \mathrm{c}$.

6. Тимирбулатов Р.А. Метод повышения интенсивности свободных радикалов окисления липидсодержащих компонентов крови и его диагностическое значение / Р.А. Тимирбулатов, Е.И. Селезнев // Лаб. дело. -1981. - № 4. - C. 209-211.

7. Чучалин А.Г. Диагностика респираторных заболеваний / А.Г. Чучалин // Респираторная медицина. Руководство. Под редакцией академика РАМН А.Г. Чучалина. - М., 2007. - Т.1. - С. 231-238.
8. Enhanced sensitivity to oxidative stress in transgenic tobacco plants with decreased glutathione reductase activity leads to a decrease in ascorbate pool and ascorbate redox state / S. Ding, Q. Lu, Y. Zhang [and others]. Plant Mol. Biol. - 2009. - Vol. 69, № 6. - P. 577-592.

9. Girard M. Pathogenesis of hypersensitivity pneumonitis M. Girard, E. Israel-Assayag, Y. Cormier // Curr Opin Allergy Clin Immunol. - 2004. - Vol. 4, № 2. - P. 93-98.

10. Lakari E. Expression of Oxidant and Antioxidant Enzymes in Human Lung and Interstitial Lung Diseases / E. Lakari. - Oulu, 2002. -86 p.

11. Pathology of hypersensitivity pneumonitis / T. Takemura, T. Akashi, Y. Ohtani [et al.] // Curr. Opin. Pulm. Med. 2008. - Vol. 14, № 5. - P. 44-54.

12. Strange RC. Glutathione S-transferase: genetics and role in toxicology / RC. Strange, PW. Jones, AA. Fryer // Toxicol Lett. - 2000. - Vol. 112, № 3. - P. 357-363.

\section{СОСТОЯНИЕ АНТИОКСИДАНТНОЙ ГЛУТАТИОНОВОЙ СИСТЕМЫ И ПРОЦЕССОВ ПЕРЕКИСНОГО ОКИСЛЕНИЯ ЛИПИДОВ В ЛЕГКИХ МОРСКИХ СВИНОК С ЭКСПЕРИМЕНТАЛЬНЫМ АЛЛЕРГИЧЕСКИМ АЛЬВЕОЛИТОМ В РАЗНЫЕ ПЕРИОДЫ ЕГО ФОРМИРОВАНИЯ}

\section{Б.Я. Мелех}

Резюме. В данной работе было установлено, что в условиях развития экспериментального аллергического альвеолита на 34-е и 44-е сутки возрастает концентрация малонового альдегида за счет усиления процессов перекисного окисления липидов. При этом на 44-е сутки наблюдается снижение активности глутатионпероксидазы и глутатионредуктазы, а также концентрации восстановленного глутатиона. Данные изменения указывают, что в патогенезе развития экзогенного аллергического альвеолита у морских свинок важную роль играют процессы перекисного окисления липидов и ферментативного и неферментативного звеньев антиоксидантной системы, а также значительное истощение ферментативного звена антиоксидантной глутатионовой системы на 44-е сутки.

Ключевые слова: глутатион, глутатионпероксидаза, глутатионредуктаза, глутатионтрансфераза, экспериментальный аллергический альвеолит.

\section{GLUTATHIONE ANTIOXIDANT SYSTEMS AND PROCESSES OF LIPID PEROXIDATION IN GUINEA PIGS' LUNGS WITH EXPERIMENTAL ALLERGIC ALVEOLITIS IN DIFFERENT PERIODS OF ITS FORMATION}

\section{B.Ya. Melekh}

Abstract. The paper established that under the conditions of the development of experimental allergic alveolitis on the $34^{\text {th }}$ and $44^{\text {th }}$ days malonic aldehyde concentration increases due to the stronger processes of lipid peroxidation. In addition on the $44^{\text {th }}$ day, a decrease in the activity of glutathione peroxidase and glutathione reductase and glutathione concentration are observed. These changes indicate that the pathogenesis of experimental allergic alveolitis in guinea pigs are important lipid peroxidation and enzymatic and non-enzymatic antioxidant system level as well as a significant depletion of the antioxidant enzyme level glutathione system on the $44^{\text {th }}$ day. alveolitis.

Key words: glutathione, glutathione peroxidase, glutathione reductase, glutathione transferase, experimental allergic Danylo Halytskyi National Medical University (Lviv) 